\title{
Recognition of separate genera within Acropora based on new morphological, reproductive and genetic evidence from Acropora togianensis, and elevation of the subgenus Isopora Studer, 1878 to genus (Scleractinia: Astrocoeniidae; Acroporidae)
}

\author{
C. C. Wallace · C. A. Chen • H. Fukami • P. R. Muir
}

Received: 12 June 2006 / Accepted: 22 January 2007 / Published online: 27 February 2007

(C) Springer-Verlag 2007

\begin{abstract}
Many attempts have been made to recognise divisions within Acropora, the most diverse reef building coral genus on modern reefs, but only subgenera Acropora and Isopora are currently recognised. In this paper, morphological and genetic analyses, and study of reproductive mode and anatomy, demonstrate that an endemic Indonesian species A. (Acropora) togianensis, Wallace, 1997, belongs to Isopora. Despite the presence of a clear central axial corallite (indicating sub-genus Acropora), this species has supplementary axial corallites, broods planula larvae rather than broadcast-spawning for external fertilisation and develops stalked ova: all characters in common with the type species of subgenus Isopora A. (Isopora) palifera and the other species for which such data are available, A. (I.) cuneata and A. (I.) brueggemanni. Phylogenies are based on the protein-coding genes,
\end{abstract}

Communicated by Biology Editor M. van Oppen.

C. C. Wallace $(\varangle) \cdot$ P. R. Muir

Museum of Tropical Queensland,

70-102 Flinders St., Townsville, 4812, Australia

e-mail: carden.wallace@qm.qld.gov.au

C. A. Chen

Research Centre for Biodiversity,

Academia Sinica, Nankang, Taipei, 115, Taiwan

C. A. Chen

Institute of Oceanography,

National Taiwan University,

Taipei, 106, Taiwan

H. Fukami

Seto Marine Biological Station,

The Kyoto University, Shirayama,

Kyoto, 649-2211, Japan mitochondrial cytochrome $b(c y t b)$ and nuclear histone $2 \mathrm{a}$ and $2 \mathrm{~b}(h 2 a b)$ also group A. togianensis with these Isoporans. High bootstrapping and Bayesian support in the major lineages of the family Acroporidae demonstrate significant differences between Isopora (including A. togianensis) and Acropora. As the type species of both subgenera, A. (Acropora) muricata (Linneaus 1758) and A. (Isopora) palifera (Lamarck, 1816) are used in these analyses, elevation of Isopora Studer, 1878 to genus is formally proposed.

Keywords Coral taxonomy $\cdot$ Coral reefs $\cdot$ Proteincoding genes $\cdot$ Coral reproduction

\section{Introduction}

The coral genus Acropora Oken 1815 (Scleractinia: Astrocoeniidae; Acroporidae) is distinguished from all other extant coral genera by a unique form of polyp structural and functional dimorphism, having branches formed by one or more central or axial corallites (polyp skeletons) which bud off a second type of corallites, the radial corallites, as they extend and grow (Wells 1956; Wallace 1978, 1999; Randall 1981; Veron and Wallace 1984). Axial corallites are cylindrical and may reach several centimetres in length, while radial corallites occur in a variety of shapes and are never more than a few millimetres long. From its confamilial genera Montipora, Anacropora and Astreopora, Acropora is further distinguished by the distinctive structures of the radial corallite walls (a wall being absent from Montipora and Anacropora and undifferentiated from a simple conical tube in Astreopora). Additionally, some species of Montipora have unique and 
various elaborations of the coenosteum, a skeletal feature outside the boundaries of the polyps.

Within Acropora, two subgenera are currently recognised on the basis of having branches formed only around a single axial corallite (nominotypic subgenus Acropora, type species Acropora muricata) or more than one axial corallite (subgenus Isopora, type species Acropora palifera). Additionally, these two subgenera have been found to have differing reproductive modes and anatomy, in all species investigated in the respective subgenera to date. In subgenus Acropora, gonads are borne within the mesenteries and fertilisation and development are external (Wallace 1985, 1999). In subgenus Isopora, oocytes are attached by a stalk to the mesenteries and fertilisation and development occur within the polyp (Kojis 1986). The other genera of extant Acroporidae have unstalked gonads and external fertilisation, as in Acropora.

Isopora was proposed as a subgenus by Studer (1878), a grouping upheld by Brook (1893) in the first full revision of the genus (interpreted as Madrepora in both publications). Brook's monograph also included numerous other subgenera, but these, including Isopora, were not generally used by later authors (Wallace 1978). Randall (1981), in a study of the modes of growth shown in various Acropora, drew attention to Isopora again. Based on absence of the single axial corallite character and different mode of growth this incurred, he proposed raising Isopora to a genus, containing three valid species, A. palifera, Acropora cuneata and Acropora crateriformis. This did not include Acropora brueggemanni, a species with the single axial corallite, but known to have internal fertilisation and development followed by expulsion of planulae (Atoda 1951). More recent taxonomic revisions (Veron and Wallace 1984; Wallace 1999) have included A. brueggemanni in the group because its branches sometimes do show more than a single axial corallite and it possesses the elaborated meandroid coenosteal spinules unique to this group of species (Wallace 1999), as well as the same reproductive characters. The frequent presence of a distinct single axial corallite in A. brueggemanni (and thus in Isopora), as in Acropora, still left a dilemma, and consequently these authors retained Isopora as a subgenus.

The question of the taxonomic status of Isopora was addressed with molecular data by Fukami et al. (2000), in a phylogeny of the family Acroporidae. Using the mitochondrial cytochrome $b$ (cytb) and ATP6 genes they found the genera Montipora and Anacropora to be phylogenetically indistinguishable: relative to this, they found significant genetic distance between Isopora (A. palifera and A. brueggemanni) and Acropora (six species, not including the type species), and proposed generic level separation of the two groups (Fukami et al. 2000).

The recently described species Acropora togianensis Wallace 1997 (known only from Central Sulawesi in Indonesia) is enigmatic because of an unusual combination of skeletal characteristics. It possesses differentiated radial and axial corallites, a feature of the genus Acropora, but lacks distinct radial corallite walls and has coenosteal elaborations, characteristics usually associated with the genus Montipora (although many species of Montipora do not have coenosteal elaborations). A. togianensis was ascribed to subgenus Acropora since the specimens examined possessed single axial corallites (Wallace 1997): however, because this species had meandroid coenosteal spinules as in the Isoporan species, this placement was described as tentative due to lack of data on other characters such as reproductive mode (Wallace 1997). In a cladistic analysis of Acropora based upon morphological characters, A. togianensis was placed within the subgenus Acropora clade, but separate from other $A$. (Acropora) species groups, the presence of the single axial corallite influencing its position: thus it was treated as a separate species group within subgenus Acropora (Wallace 1999).

The "Tethyana" expedition to the only known location of A. togianensis, the Bay of Tomini in Central Sulawesi (Wallace et al. 2003), gave an opportunity to collect further material including tissue samples, in order to examine the morphology of this species in more detail, study its reproductive patterns and use molecular characters in a phylogeny. This paper reports on the findings of these studies and revises the taxonomic position of $A$. togianensis, based on the results. The proposal for generic status of Isopora as put forward by Randall (1981) and Fukami et al. (2000) is reviewed and upheld in the light of these findings.

\section{Materials and methods}

\section{Location}

Field sampling for $A$. togianensis and other species was done in October 1999 in the Togian Islands, Central Sulawesi, Indonesia, centred at latitude $00^{\circ} \mathrm{N}$, longitude $122^{\circ} \mathrm{E}$ (Wallace et al. 2003), following earlier sampling of the type series in the same area in 1995 (Wallace 1997). A. togianensis colonies were examined in situ using SCUBA and samples were taken for histological, morphological and genetic analyses. Samples of other species and genera were taken from the Togian 
Island sites for molecular phylogenetic analyses, and additional samples of other species and genera, from sites outside the Togian Islands, were used in the genetic analyses as indicated in Table 1.

\section{Morphology}

Samples for skeletal morphology were bleached (commercial 3\% hypochlorite solution), rinsed in freshwater and dried. Twenty-two specimens of $A$. togianensis (including the types series) were lodged in the WorldWide Acropora Collection at the Museum of Tropical Queensland, Australia. Using a stereo dissecting microscope, each branch tip on 22 A. togianensis samples was examined to determine the number of axial corallites (111 tips total). The tip was defined as the area within the first centimetre of the apex of an intact branch. Thin skeletal sections of branch tips of
A. togianensis were made using a geological microtome at James Cook University, Townsville.

\section{Reproduction}

Branch tips from five A.togianensis colonies were fixed in $5 \%$ formaldehyde solution in seawater in the field and stored in $70 \%$ ethyl alcohol. These samples were decalcified using formic acid (5\% v/v). Decalcified specimens were dissected under a stereo dissecting microscope: individual polyps were examined for the presence of gametes and/or brooded larvae. Portions of specimens were prepared for histological analyses by dehydrating through a graded series of ethanols (75, $95,100,100 \% \mathrm{v} / \mathrm{v})$, infiltrating and embedding in paraffin wax. Sections were cut by microtome, stained with Mallory Hiedenhiem Trichrome and examined using a Leitz high power photomicroscope. Each histological
Table 1 Taxonomic information, sampling locations, Genbank accession numbers, and references for mitochondrial cytochrome $b$ and nuclear histone $h 2 a b$ genes used in this study

\footnotetext{
${ }^{\text {a }}$ Fukami et al. (2000)

b van Oppen et al. (1999)

c Present study
}

\begin{tabular}{|c|c|c|c|}
\hline Taxon & Sampling location & Cytochrome $b$ & Histone $2 a b$ \\
\hline Isopora togianensis & Togian Islands, Sulawesi & AF310137 & $\begin{array}{l}\text { EF363331 } \\
\text { EF363335 }\end{array}$ \\
\hline Isopora palifera & $\begin{array}{l}\text { Ishigaki Island, Okinawa/ } \\
\text { Kenting, Taiwan }\end{array}$ & $\begin{array}{l}\mathrm{AB} 033175^{\mathrm{a}} \\
-\end{array}$ & $\begin{array}{l}- \\
\text { EF363327 }\end{array}$ \\
\hline Isopora cuneata & Togian Islands, Sulawesi & - & EF363328 \\
\hline Isopora brueggemanni & $\begin{array}{l}\text { Ishigaki Island, Okinawa/ } \\
\text { Togian Islands, Sulawesi }\end{array}$ & $\begin{array}{l}\mathrm{AB} 033176^{\mathrm{a}} \\
-\end{array}$ & $\begin{array}{l}- \\
\text { EF363330 }\end{array}$ \\
\hline Acropora humilis & $\begin{array}{l}\text { Togian Islands, Sulawesi } \\
\text { /Tahiti }\end{array}$ & $\begin{array}{l}\text { EF363316 } \\
\text { EF363315 }\end{array}$ & $\begin{array}{l}\text { EF363326 } \\
\text { EF363325 }\end{array}$ \\
\hline Acropora digitifera & Ishigaki Island, Okinawa & $\mathrm{AB} 033177^{\mathrm{a}}$ & - \\
\hline Acropora gemmifera & Ishigaki Island, Okinawa & $\mathrm{AB} 033178^{\mathrm{a}}$ & - \\
\hline Acropora nasuta & Ishigaki Island, Okinawa & $\mathrm{AB} 033179^{\mathrm{a}}$ & - \\
\hline Acropora cerealis & Magnetic Island Australia & AF099652 & - \\
\hline Acropora latistella & Magnetic Island Australia & AF099656 $6^{\mathrm{b}}$ & - \\
\hline Acropora millepora & Magnetic Island Australia & AF099653 ${ }^{b}$ & - \\
\hline Acropora valida & $\begin{array}{l}\text { Magnetic Island Australia } \\
\text { Penghu Island, Taiwan }\end{array}$ & $\begin{array}{l}\text { AF099658 } \\
-\end{array}$ & $\begin{array}{l}- \\
\text { EF363324 }\end{array}$ \\
\hline Acropora muricata & $\begin{array}{l}\text { Magnetic Island Australia/ } \\
\text { Penghu Island, Taiwan }\end{array}$ & AF099651 & $\bar{L} 11067^{c}$ \\
\hline Acropora cervicornis & San Blas Island Panama & AF099654 & - \\
\hline Acropora palmata & San Blas Island Panama & AFO99655 & - \\
\hline Acropora donei & Ishigaki Island, Okinawa & $\mathrm{AB} 033180^{\mathrm{a}}$ & - \\
\hline Acropora tenuis & Ishigaki Island, Okinawa & $\mathrm{AB} 033181^{\mathrm{a}}$ & - \\
\hline Acropora hyacinthus & Penghu Island, Taiwan & - & EF363323 \\
\hline Acropora cytherea & Penghu Island, Taiwan & - & EF363322 \\
\hline Acropora florida & Ishigaki Island, Okinawa & $\mathrm{AB} 033182^{\mathrm{a}}$ & - \\
\hline Astreopora myriophthalma & Ishigaki Island, Okinawa & AB $033171^{\mathrm{a}}$ & - \\
\hline Montipora digitata & Ishigaki Island, Okinawa & $\mathrm{AB} 033172^{\mathrm{a}}$ & - \\
\hline Montipora cactus & Penghu Island, Taiwan & - & EF363320 \\
\hline Montipora efflorescens & $\begin{array}{l}\text { Ishigaki Island, Okinawa/ } \\
\text { Penghu Island, Taiwan }\end{array}$ & AB033173 & $\begin{array}{l}- \\
\text { EF363319 }\end{array}$ \\
\hline Montipora aequituberculata & Ishigaki Island, Okinawa & $\mathrm{AB} 033172^{\mathrm{a}}$ & - \\
\hline Montipora altasepta & Ishigaki Island, Okinawa & $\mathrm{AB} 033175^{\mathrm{a}}$ & - \\
\hline Anacropora sp.1 & Ishigaki Island, Okinawa & $\mathrm{AB} 033174^{\mathrm{a}}$ & - \\
\hline Anacropora matthai & Togian Islands, Sulawesi & - & EF363321 ${ }^{\mathrm{c}}$ \\
\hline Anacropora sp.2 & Ishigaki Island, Okinawa & $\mathrm{AB} 033177^{\mathrm{a}}$ & - \\
\hline Favites abdita & Penghu Island, Taiwan & - & EF363318 \\
\hline Platygyra sinensis & Penghu Island, Taiwan & - & EF363317 \\
\hline
\end{tabular}


series contained at least 20 complete sectioned polyps. These were examined for the presence and structure of oocytes, testes and planula larvae.

Genetic analyses

\section{Samples}

Tissue samples collected from the Togian Islands for A. togianensis, A. palifera, A. brueggemanni, A. cuneata, Acropora digitifera, and $A$. muricata and were preserved in $95 \%(\mathrm{v} / \mathrm{w})$ ethanol. Skeletal voucher samples were kept for the validation of the identities of these samples. Sperm samples were collected by separation of egg-sperm bundles from spawning colonies of $A$. muricata, A. digitifera, Acropora hyacinthus, Acropra cytherea and Acropora valida in Kenting National Park, southern Taiwan in 1997, and from spawning colonies of Montipora cactus, Montipora efflorescens, Anacropora matthai, Favites abdita, and Platygyra sinensis in the Penghu Islands in 1998 and 1999. Samples were frozen in liquid nitrogen or dry ice for transfer to the laboratory.

\section{DNA extraction, amplification, cloning and sequencing}

Extraction followed methods described in Chen and $\mathrm{Yu}$ (2000) and Chen et al. (2000). Targeted segments of the cytochrome $b$ (cytb) gene were amplified using the primers and polymerase chain reaction (PCR) conditions described in van Oppen et al. (1999). The sequences containing partial histone $2 \mathrm{~A}$ and $2 \mathrm{~B}(h 2 a b)$ gene and an intron in between were amplified using primers $h 2 a b$-F: $5^{\prime}-\mathrm{TTG}(\mathrm{G} / \mathrm{C})(\mathrm{A} / \mathrm{T}) \mathrm{GCTGGT}(\mathrm{G} / \mathrm{A})$ TACTTGGTCAC $-3^{\prime}$ and $h 2 a b-\mathrm{R}: 5^{\prime}-\mathrm{AG}(\mathrm{A} / \mathrm{C}) \mathrm{AG}$ (T/C)TTGTTCAATTCCTCGTC-3', which were designed from the alignment of the histone gene cluster from A. muricata (Miller et al. 1993). The amplified $h 2 a b$ PCR products corresponded to the region between 1,468 and 2,642 bp in the published histone gene cluster of $A$. muricata (Miller et al. 1993). PCR was performed in a PC-9606 thermal sequencer (Corbett Research) using the following thermal cycle: 1 cycle at $95^{\circ} \mathrm{C}(4 \mathrm{~min}) ; 4$ cycles at $94(30 \mathrm{~s}), 50(1 \mathrm{~min})$, and $72^{\circ} \mathrm{C}(2 \mathrm{~min})$; and 30 cycles at $94(30 \mathrm{~s}), 55(1 \mathrm{~min})$, and $72^{\circ} \mathrm{C}(2 \mathrm{~min})$. The amplification reaction used 50 $200 \mathrm{ng}$ of template and BRL Taq polymerase in a 50$\mu l$-volume reaction, using the buffer supplied with the enzyme, under conditions recommended by the manufacturer. The PCR products were electrophoresed in a $1 \%$ agarose (FMC Bioproduct) gel in $1 \times$ TAE buffer to assess the yield, and cloned using the pGEM-T system (Promega) under conditions recommended by the manufacturer. Nucleotide sequences were determined for complementary strands of at least two clones from each sample using an ABI 377 Genetic Analyzer. The sequences obtained were submitted to GenBank under the accession numbers EF363315-EF363335.

\section{Sequence alignment and phylogenetic analyses}

Sequences of the mtDNA cytb gene (van Oppen et al. 1999; Fukami et al. 2000) were retrieved from GenBank, and aligned to the cytb sequences obtained in this study (Table 1). DNA sequences of the $h 2 a b$ gene were initially aligned using CLUSTAL W 1.7 (Thompson et al. 1994), followed by manual editing based on translation of the corresponding amino acid sequences of A. muricata (Miller et al. 1993) using SeqApp 1.9 (Gilbert 1994). The intron spanning between the $h 2 a$ and $h 2 b$ genes was excluded due to high variability among the genera of Acroporidae and outgroups.

Phylogenetic analyses were performed using PAUP 4.0b10 (Swofford 2002). Neighbor-joining (NJ), maximum likelihood (ML), and Bayesian analyses were also performed. Bootstrapping with 1,000 pseudoreplicates was used to examine the robustness in the resulting trees. For the NJ and ML analyses, the best-fit model of DNA substitution and the parameter estimates used for tree construction were chosen by performing hierarchical likelihood-ratio tests for $c y t b$ and $h 2 a b$ genes, respectively, using PAUP 4.0b10 and Modeltest 3.07 (Posada and Buckley 2004). Likelihoodratio tests indicated that the $\mathrm{HKY}+\mathrm{G}$ model with a gamma distribution-shaped parameter of 0.1704 and $\mathrm{K} 80+\mathrm{G}$ model with a gamma distribution-shaped parameter of 0.7615 were most appropriate for $c y t b$ and $h 2 a b$, respectively, in the subsequent ML analyses. The Bayesian tree reconstruction was implemented using the "MrBayes" program (Ronquist and Huelsenbeck 2003). Bayesian tree reconstructions were inferred using the same model of DNA evolution as for the ML analyses. Five simultaneous Markov chains were run for 1,000,000 generations with a tree sampled every 10 generations, with 50,000 initial trees discarded as burn-in, based on visual inspection.

\section{Results}

\section{Morphology of Acropora togianensis}

Of 111 A. togianensis branch tips examined, 26\% (29 tips) possessed more than one axial corallite, with a maximum of seven axial corallites seen on a tip (Fig. 1). Most tips came from branches randomly 
Fig. 1 Isopora togianensis skeletal morphology. a Entire juvenile colony, all branches showing a single axial corallite in the tip region. b Off-centre section of branch, showing two supplementary axial corallites below the main axial corallite opening. c Branch tip showing multiple axial corallites. d Central thin section of branch showing continuous central axial corallite throughout. Scale a and $\mathbf{c} 10 \mathrm{~mm}, \mathbf{b}$ and $\mathbf{d} 5 \mathrm{~mm}$
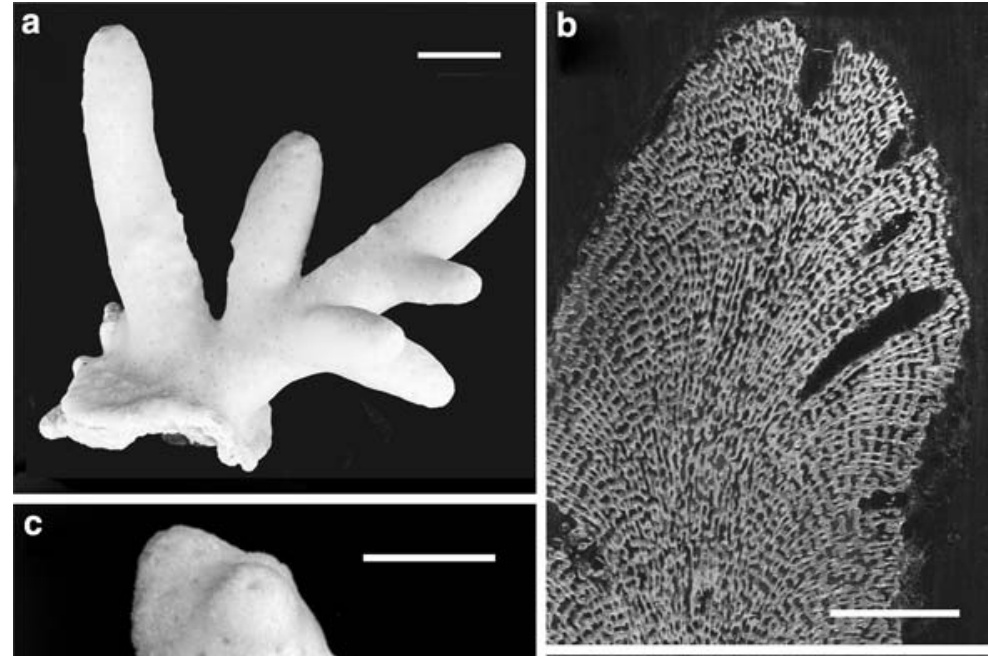

d

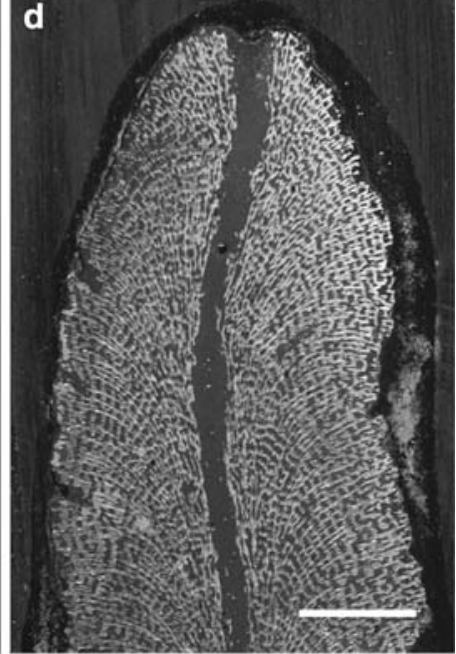

collected from large colonies in the field: however, an entire juvenile colony was sampled in one instance and this had only a single axial corallite in each branch (Fig. 1a). When multiple-tipped branch tips were thinsectioned, it could be seen that a central axial corallite ran right through the branch, as in Fig. 1d: however, the "supplementary" axial corallites were shorter than this (Fig. 1b). This could also be seen in decalcified specimens, where a long central axial polyp and one or more axial polyps, shorter than the central polyp but longer than radial polyps, could be seen (Fig. 2a).
Mode of reproduction in Acropora togianensis

Planula larvae were present in polyps within three of the five sectioned tissue samples (Fig. 2b; Table 2). Polyp sections contained planulae, testes and oocytes, planulae and oocytes only, testes and oocytes only or oocytes only (Table 2). Planulae ranged in length from 300 to $1,500 \mu \mathrm{m}$, some larger planulae showing advanced internal differentiation (Fig. 3a). Oocytes were 100-250 $\mu \mathrm{m}$ in diameter and were connected to the mesenteries by a short stalk (Fig. 3b, d). Testes were loculated at various
Fig. 2 a Dissected tip sample of Isopora togianensis showing central axial corallite $(A)$, with one supplementary axial corallite to the left and numerous radial corallites $(R)$. b Single polyp showing single mature planula larva $(P)$ in the polyp cavity. Testes can be seen on mesenteries $(T)$. Scale a $5 \mathrm{~mm}$, b $1 \mathrm{~mm}$
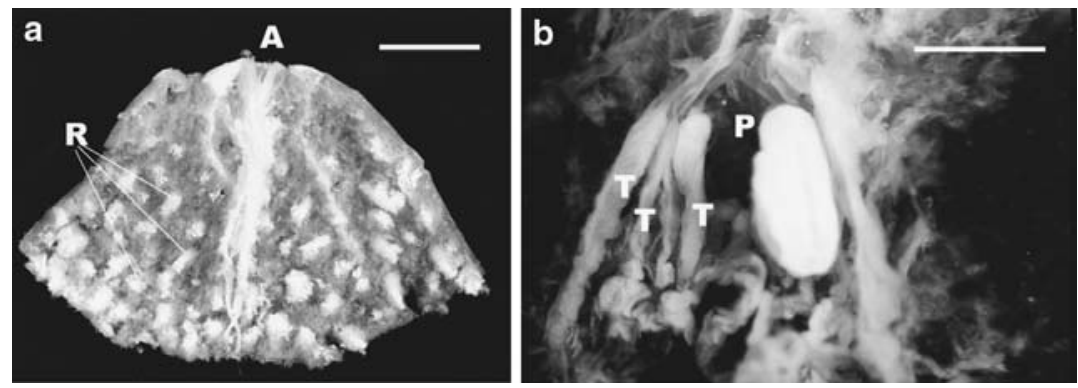
Table 2 Reproductive status of Isopora togianensis polyps in histology samples

\begin{tabular}{llll}
\hline Sample no. & Oocytes & Testes & Planulae \\
\hline 4378 & + & + & + \\
4379 & + & + & - \\
4377 & + & - & + \\
4376 & + & + & + \\
4383 & + & - & - \\
\hline
\end{tabular}

developmental stages including mature sperm flagella present in the central lumen (Fig. 3c).

DNA sequence characteristics and phylogenetic analyses

The aligned $c y t b$ gene was 963 bp in length with 58 phylogenetic-informative nucleotides (6\%). Mean genetic distance within the phylogeny of the Acroporidae based on the $c y t b$ gene with the HKY model was 0.034 . Genetic distances between genera are given in Table 3 (A. togianensis is included within the Isoporans

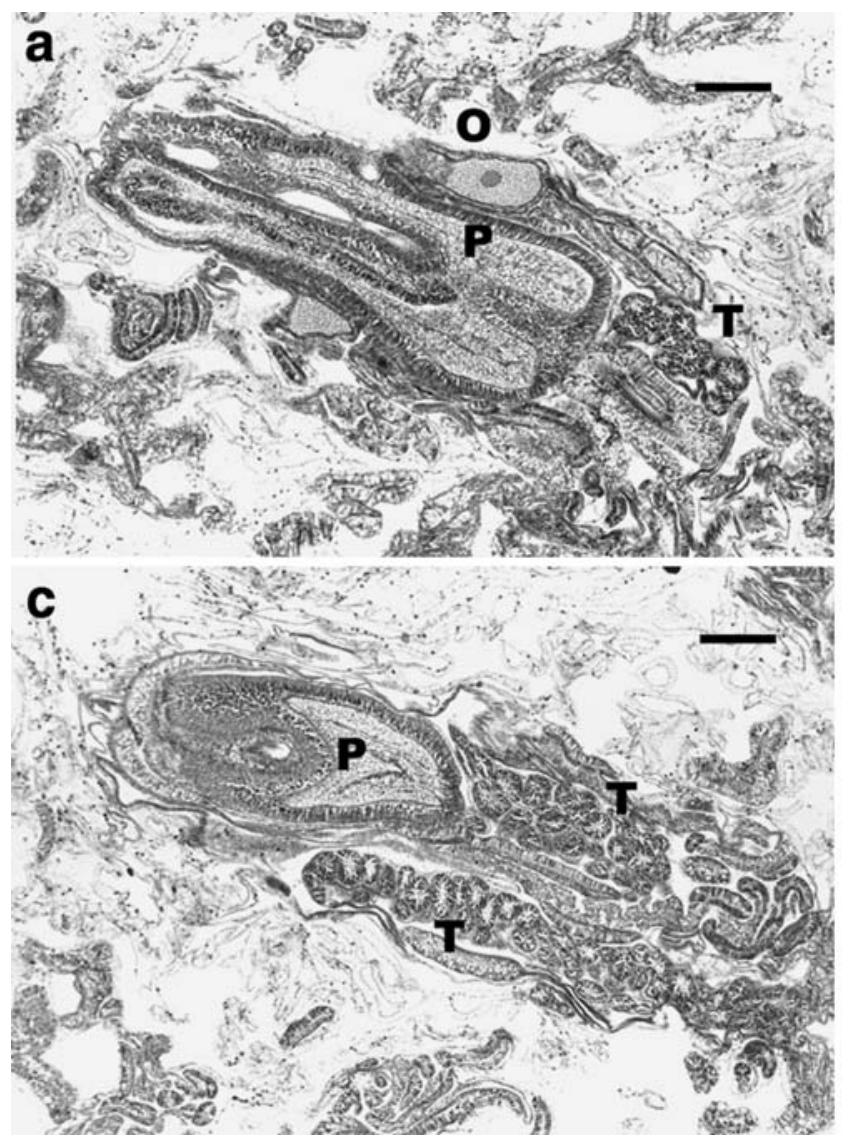

Fig. 3 Histological sections of Isopora togianensis corallites showing a presence of oocyte $(O)$, testes $(T)$ and mature planula larva $(P)$; b oocytes only $(O)$; c mature testes $(T)$ and mature or for this table, based on gene substitutions). The mean genetic distance between Acropora and Isopora is more than five times higher than that between the genera Montipora and Anacropora, which are genetically indistinguishable.

Divergence of the $h 2 a b$ protein-coding gene among the Acropora species was higher than that of $c y t b$ gene. Amongst the 620-bp nucleotides, nine deletions corresponding to three amino acid deletions were observed between the outgroup formed by Platygyra sinensis and Favites abdita, and the family Acroporidae, at positions 289-294 and 338-340. Within the Acroporidae, three nucleotide deletions equal to one amino acid deletion occurred between the MontiporalAnacropora clade and the Isopora and Acropora clade at positions 289-291. Of the 620 characters, 169 (27\%) were phylogenetically informative. In this case the mean genetic distance between Acropora and Isopora was again five times higher than that between the genera Montipora and Anacropora. Mean genetic distance among the Acroporidae genera based on the K80 model was 0.076, twice than that seen using cytb (Table 4).

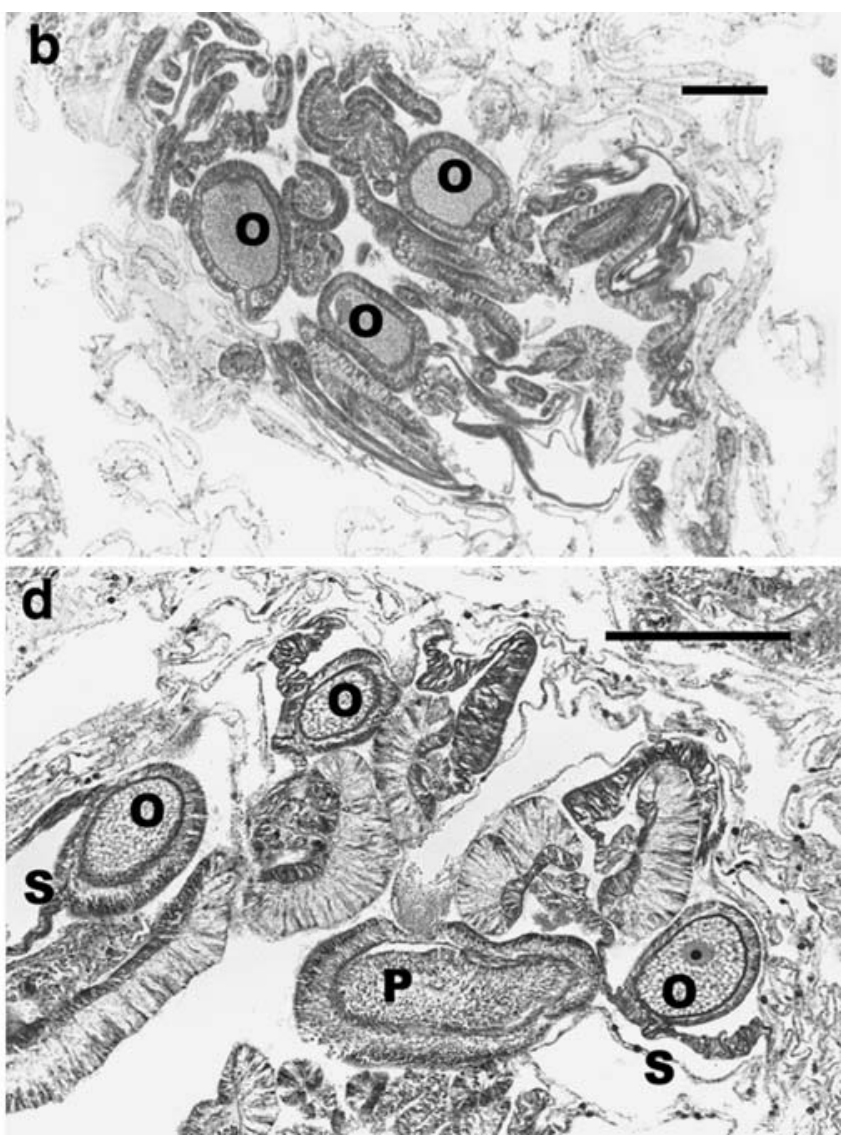

almost mature planula larva $(P)$; d planula larva $(P)$ and oocytes $(O)$, one showing stalked attachment to mesentery $(S)$. Scale $200 \mu \mathrm{m}$ 
Table 3 Mean and range of pair-wise genetic distances between genera in the family Acroporidae, using the Cytochrome $b$ gene

\begin{tabular}{lllll}
\hline Genus & Acropora & Isopora & Montipora & Anacropora \\
\hline Acropora & $0.004(0-0.015)$ & & & \\
Isopora & $0.021(0.17-0.028)$ & $0.002(0-0.003)$ & $0.004(0.003-0.005)$ & 0.004 \\
Montipora & $0.068(0.059-0.081)$ & $0.056(0.049-0.061)$ & $0.004(0.003-0.005)$ & $0.085(0.082-0.087)$ \\
Anacropora & $0.074(0.069-0.086)$ & $0.060(0.057-0.062)$ & $0.081(0.080-0.084)$ & \\
Astreopora & $0.132(0.127-0.142)$ & $0.126(0.122-0.131)$ & &
\end{tabular}

Table 4 Mean and range of pair-wise genetic distances between genera in the family Acroporidae, using the Histone $h 2 a b$ gene

\begin{tabular}{lllll}
\hline Genus & Acropora & Isopora & Montipora & Anacropora \\
\hline Acropora & $0.0097(0.001-0.016)$ & & & \\
Isopora & $0.044(0.039-0.049)$ & $0.004(0.002-0.006)$ & 0 & 0.008 \\
Montipora & $0.211(0.209-0.215)$ & $0.223(0.221-0.229)$ & $0.220(0.218-0.227)$ & 0 \\
Anacropora & $0.214(0.212-0.218)$ & 0.220 & \\
\hline
\end{tabular}

Phylogenetic analyses of the cytb DNA sequences using NJ, ML, and Bayesian (Fig. 4) produced similar topologies to those obtained by Fukami et al. (2000). $A$. togianensis, which was not included in the latter analysis, grouped with $A$. brueggemanni, and $A$. palifera by significantly high bootstrapping support and Bayesian probabilities (Fig. 4), supporting placement of this species in Isopora. The close relationship between $A$. togianensis, A. cuneata and other Isopora was supported by the $h 2 a b$ phylogeny, which also supported the distinction between Isopora and Acropora and the relationships amongst the genera of Acroporidae (Fig. 5).

\section{Discussion}

In this paper we were seeking clarification of the subgeneric position of $A$. togianensis, which has elaborate meandroid coenosteal spinules, otherwise known only from subgenus Isopora (Wallace 1997). We have observed supplementary corallites contributing to the structure of a branch, a feature also seen in the Isoporan A. brueggemanni. We have also shown that $A$. togianensis broods planula larvae, a reproductive mode exclusive to subgenus Isopora in the family Acroporidae, and that it bears stalked ova as in Isopora. From these characteristics we propose that A. togianensis is an Isoporan, based on morphology and reproductive characters.

Placement of A. togianensis in Isopora based on morphology and reproduction is corroborated by the phylogenetic analyses based on the cytb gene and the $h 2 a b$ protein-coding gene sequence. Using these genetic markers for a phylogeny of the family, we have shown A. togianensis to group with other Isoporan representatives $A$. palifera (the type species of Isopora), A. brueggemanni and $A$. cuneata.

Fig. 4 Phylogenetic tree of Acroporidae using Cytochrome $b$ (cytb) gene with Astreopora as an outgroup. Numbers above branches are NJ bootstrap values, $M L$ bootstrap values, and the Bayesian posterior probabilities (in percentage), respectively. Abbreviation for the country of sampling follows species name $A$ Australia, $I$ Indonesia, $J$ Japan, $S$ Samoa, $T$ Taiwan, $T h$ Tahiti

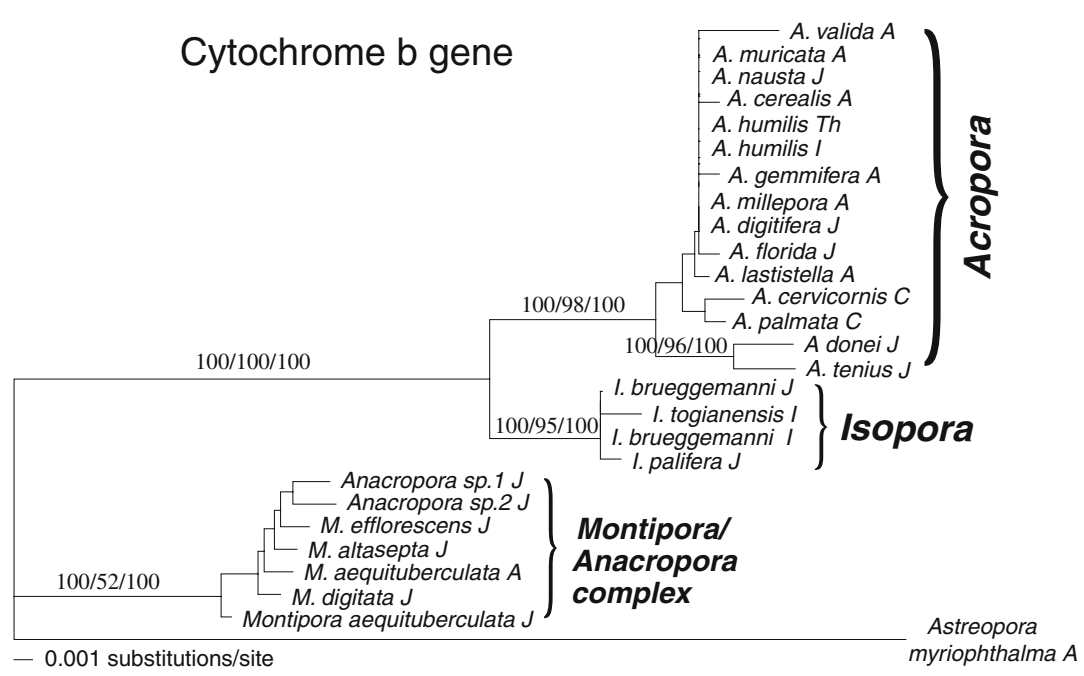


Fig. 5 Phylogenetic tree of Acroporidae using Histone $2 \mathrm{a}$ and $2 \mathrm{~b}(h 2 a-b)$ genes, with

Platygyra sinensis and Favites abdita as outgroups. Numbers above branches are NJ bootstrap values, $M L$ bootstrap values, and the Bayesian posterior probabilities (in percentage), respectively. For abbreviations of sampling localities see Fig. 4

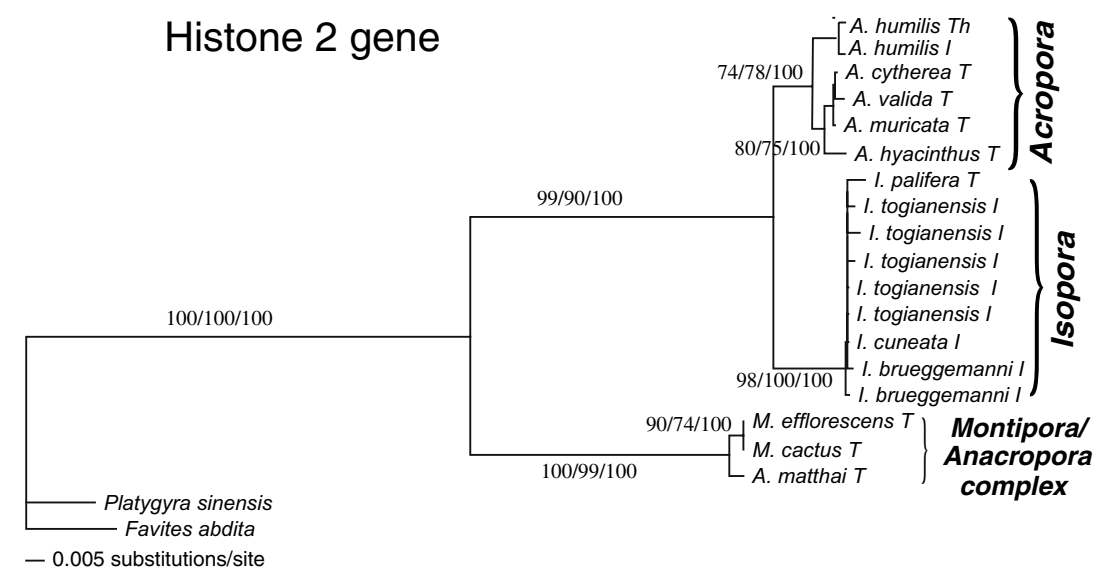

The molecular characteristics of the Acropora cytb DNA sequences obtained in this study were similar to those published in previous studies, which showed very low genetic divergence amongst the species (van Oppen et al. 1999; Fukami et al. 2000). The addition of $A$. togianensis and $A$. cuneata confirms the separation of a clade of Isoporans from Acropora, as seen by Fukami et al. (2000). In contrast to this, the genera Montipora and Anacropora remain unresolved on the basis of genetic characters, as in Fukami et al. (2000).

The presence of two well-supported clades of the sister taxa "Acropora" and "Isopora" within the monophyletic Acropora/Isopora clade in both phylogenetic analyses supports the proposal for elevation of Isopora to genus (Fukami et al. 2000). This combined evidence from morphology, life history and genetics supports separation of the two subgenera at generic level and elevation of the subgeneric name Isopora to genus. Accordingly, below we propose descriptions of the two genera, based on the original descriptions and subsequent information.

\section{Family Acroporidae Verrill, 1902}

Massive or ramose colonies by extratentacular budding; corallites small, synapticulothecate, pseudocostate, slightly differentiated from coenosteum. Septa non-exert, in two cycles, formed by simple spiniform trabeculae projecting inward and upward from vertical mural trabeculae, commonly fusing to form laminae. Columella absent or trabecular and weak. Dissepiments thin and tabular when developed. Coenosteum extensive, light reticulate, flaky, generally spinose or striate on surface. Polyps hermaphrodite with external or internal fertilization followed by external or internal larval development, respectively. Late cretaceous to recent.
Genus Acropora Oken, 1815

Acropora Oken, 1815 p 66; validated 1963 (Boschma 1961; China 1963).

Type species: Acropora muricata (Linnaeus, 1758).

Type locality: Recent, Indonesia, Ambon.

Neotype: Museum of Tropical Queensland, G49167.

Diagnosis: Acroporidae which are ramose, rarely encrusting, branching with a single axial or leading corallite larger than the more numerous radial corallites budded from it; united by light, reticulate, spinose, costate or pseudocostate coenosteum. Columella and dissepiments absent. Polyps hermaphrodite, oocytes and testes borne within the mesenterial filaments on separate mesenteries; reproduction by release of eggsperm bundles followed by external fertilization and larval development. Paleocene to Recent.

\section{Genus Isopora Studer, 1878}

Isopora Studer, 1878, p 539.

Type species: Astrea palifera Lamarck, 1816 [as senior synonym of Madrepora labrosa Dana, 1846 as used by Studer (1878) as the type species].

Type locality: "Southern Ocean".

Holotype: Museum National d'Histoire Naturelle, Paris, Z301a.

Diagnosis: Acroporidae which are cuneiform, encrusting, or ramose, with multiple axial or leading corallites, or a tendency towards more than a single axial corallite, per branch, and numerous radial corallites. Coenosteum with elaborated meandroid spinules; columella and dissepiments absent. Polyps hermaphrodite, with oocytes and testes borne on separate mesenteries, mature oocytes contained in stalked extensions of the mesenterial filaments. Reproduction by release of sperm followed by internal fertilization and larval development. Pliocene to Recent. 
Acknowledgments The authors thank: Z. Florian for photography; James Cook University Histology Laboratory for use of facilities and assistance; Indonesian Institute of Sciences (LIPI) for sponsorship of research in Indonesia; M. Erdmann, A. MehtaErdmann, M. Aw, C. Paporakis, Murex Dive Resort and members of the Tethyana Expedition for support in Indonesia; Y. Chuang for phylogenetic analyses; staff of the Penghu Marine Biology Research Centre (facility of the Taiwan Fishery Research Institute), for assistance during coral spawning and J. Wolstenholme for the Acropora humilis samples. This work was supported by grants from the Australian Research Council to CCW, Academia Sinica Thematic Grants (2002-2004) and Research Centre for Biodiversity, Academia Sinica (RCBAS) Taiwan to CAC. This is the Evolution and Ecology Group, RCBAS contribution no. 45 .

\section{References}

Atoda K (1951) The larva and postlarval development of the reefbuilding corals. 3 Acropora brueggemanni (Brook). J Morphol 89:1-15

Boschma H (1961) Acropora Oken, 1815 (Anthozoa, Madreporaria): proposed validation under the plenary powers. Bulletin of Zoological Nomenclature 18:334-335

Brook G (1893) The genus Madrepora. Catalogue of the Madreporarian corals in the British Museum (Natural History) 1:1212

Chen CA, Yu JK (2000) Universal primers for amplification of mitochondrial small subunit ribosomal RNA-encoding gene in scleractinian corals. Mar Biotechnol 2:146-153

Chen AC, Wallace CC, Yu JK, Wei VN (2000) Nuclear subunit ribosomal RNA in corals. Mar Biotechnol 2:558-570

China WE (1963) Opinion 674: Acropora Oken, 1815 (Anthozoa, Madreporaria): validated under the plenary powers. Bulletin of Zoological Nomenclature 20:319-330

Fukami H, Omori M, Hatta M (2000) Phylogenetic relationships in the coral family Acroporidae, reassessed by inference from the mitochondrial genes. Zool Sci 17:689-696

Gilbert DC (1994) SeqApp 1.9. A biological sequence editor and analysis program for Macintosh computers. Available from http://www.iubio.bio.indiana.edu/IUBio-Software+Data/ molbio/seqapp/

Kojis BL (1986) Sexual reproduction in Acropora (Isopora) (Coelenterata: Scleractinia). I. A. cuneata and A. palifera on Heron Island, Great Barrier Reef. Mar Biol 91:291-309

Lamarck JBP de (1816) Histoire naturelle des animaux sens vertebres. Paris 2:1-568

Linneaus C (1758) Systema naturae (edn 10) 1:533-1327

Miller DJ, Harrison PL, Mahony TJ, McMillan JP, Miles A, Odorico DM, ten Lohuis MR (1993) Nucleotide sequence of the histone gene cluster in the coral Acropora formosa (Cnidaria; Scleractinia): features of histone gene structure and organization are common to diploblastic and triploblastic metazoans. J Mol Evol 37:245-253

Oken L (1815) Steinkorallen. Lehrbuch Naturgeschichte 3:59-74 van Oppen MJH, Willis BL, Miller D (1999) Atypically low rate of cytochrome $b$ evolution in the scleractinian coral genus Acropora. Proc R Soc Lond B 266:179-183

Posada D, Buckley TR (2004) Model selection and model averaging in phylogenetics: advantages of the AIC and Bayesian approaches over likelihood ratio tests. Syst Biol 53:793-808

Randall RH (1981) Morphological diversity in the scleractinian genus Acropora. Proc 4th Int Coral Reef Symp 2:157-164

Ronquist F, Huelsenbeck JP (2003) MrBayes3: Bayesian phylogenetic inference under mixed models. Bioinformatics 19:1572-1574

Studer T (1878) Zweite Abtheilung der Anthozoa Polyactinia, whelche wahrend der Reise A. M. S. Corvette Gazelle um die gesmmelt wurden. Monatsberichte der Königlich Preussischen der Wissenschaften zu Berlin 1878, pp 525-550

Swofford DL (2002) PAUP 4.10b: phylogenetic analysis using parsimony (and other methods). Sinauer Associates, Sunderland

Thompson JD, Higgins DG, Gibson TJ (1994) CLUSTAL X: improving the sensitivity of progressive multiple sequence alignments through sequence weighting, position-specific gap penalties and weight matrix choice. Nuclei Acids Res 22:4673-4680

Veron JEN, Wallace CC (1984) Scleractinia of Eastern Australia. Part V. Family Acroporidae. Australian Institute of Marine Science, Townsville

Verrill AE (1902) Notes on corals of the genus Acropora (Madrepora Lam.) with new descriptions and figures of types, and of several new species. Trans Conn Acad Arts Sci 11:207-266

Wallace CC (1978) The coral genus Acropora (Scleractinia: Astrocoeniina: Acroporidae) in the central and southern Great Barrier Reef Province. Mem Qld Mus 18:273-319

Wallace CC (1985) Reproduction, recruitment and fragmentation in nine sympatric species of the coral genus Acropora. Mar Biol 88:217-233

Wallace CC (1997) New species and new records of recently named species of the coral genus Acropora from Indonesian reefs. Zool J Linn Soc 120:27-50

Wallace CC (1999) Staghorn Corals of the World: a revision of the coral genus Acropora (Scleractinia; Astrocoeniina; Acroporidae) worldwide, with emphasis on morphology, phylogeny and biogeography. CSIRO Publishing, Melbourne

Wallace CC, Paulay G, Hoeksema BW, Bellwood DR, Hutchings PA, Barber PH, Erdmann M, Wolstenholme J (2003) Nature and origins of unique high diversity reef faunas in the Bay of Tomini, Central Sulawesi: the ultimate "center of biodiversity"? Proc 9th Int Coral Reef Symp 1:185-192

Wells JW (1956) Scleractinia. In: Moore RC (ed) Treatise on invertebrate paleontology Part F Coelenterata. Geological Society of America and University of Kansas Press, Kansas pp 328-444 